Archived version from NCDOCKS Institutional Repository http://libres.uncg.edu/ir/asu/

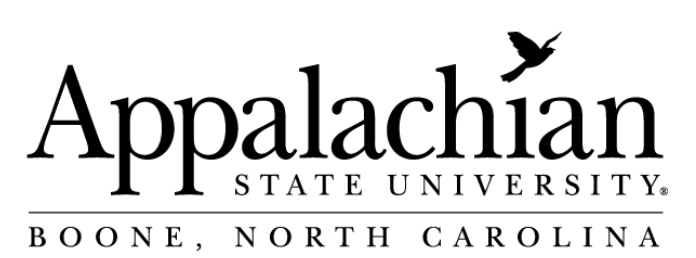

\title{
Graduate Women's Studies: An Assessment After Two Decades
}

By: Jean Reith Schroedel, Karen Torjesen, Pamela Zeiser, Charles C. Turner And Laura Ammon

No Abstract

Schroedel, Jean; Torjesen,Karen; Zeiser,Pamela; Turner,Charles C. \& Ammon,Laura (1999) "Graduate Women's Studies: An Assessment after Two Decades". Women's Studies (Vol. 28, pp. 201-219) ISSN (0049-7878) Version Of Record Available From www.tandfonline.com 


\section{Graduate Women's Studies: An Assessment after Two Decades}

\section{INTRODUCTION}

The rapid growth in the field of women's studies in recent years has led to the creation of women's studies programs across the country. In 1977 when the National Women's Studies Association was founded, there were a total of 276 undergraduate women's studies programs in the country and by 1990 there were 621. Graduate education in women's studies has developed more slowly. In 1986 there were only 23 institutions offering degrees, certificates, or women's studies concentrations within a discipline and today there are over $100 .^{2}$

Despite the growing interest in graduate women's studies education, most scholarly work in the field has focused on the development of undergraduate women's studies programs and curriculum. ${ }^{3}$ Only a small subset of scholars have addressed issues specifically of importance to graduate education in women's studies. Chamberlain (1988: 158) notes that graduate 
programs have "not yet begun to reach full growth," and GuySheftall and Heath (1995) point out that incorporating feminist approaches to professional programs (e.g., nursing, social work etc.) might be a way to facilitate the development of additional graduate women's studies programs. Other scholars have used the case study methodology to study the development of a single graduate program or provided personal reflections about the development of graduate women's studies education (Leatherman 1996; Shteir 1996). Allen (1997) is the most recent example of an insightful work reflecting on the general status of women's studies. Her main concern is that many of the programs (undergraduate and graduate) that have developed over the past quarter of a century are "institutionally fragile" which leaves them open to budget-cutting endeavors. ${ }^{4}$ To protect themselves, Allen argues that programs need to provide "a clear rationale to funders" (362). ${ }^{5}$ Although often insightful, previous studies are not amenable to generalizations about the overall state of graduate education in women's studies.

This research project was designed to fill in some of the gaps in our knowledge about graduate women's studies education. Like Allen (1997), we are interested in the long-term viability of women's studies as an academic endeavor. We believe that it is essential to gain a more generalized and systematic understanding of the current state of graduate women's studies if one wants to realistically assess its prospects in the twenty-first century. At the most general level, we wanted to determine the degree of student interest in graduate education in women's studies (i.e., whether there is an untapped market for graduate women's studies) and if so, what particular type of curriculum has the most growth potential. In addition, we wanted to determine the extent to which existing graduate programs and course offerings match the preferences of prospective students. ${ }^{6}$

\section{METHODOLOGY}

The original data analyzed in this study was obtained through two surveys conducted in early 1998. To assess prospective 
student interest in graduate women's studies, we developed a four pages long survey instrument ${ }^{7}$ that began by asking respondents to provide basic demographic information about themselves and then moved on to a series of questions covering their general level of interest in graduate programs in women's studies and more detailed questions about the types of curriculum that most interested them. The survey was administered to 403 students enrolled in undergraduate introductory women's studies classes at eleven colleges and univer-sities. Although it was not possible to randomly choose institutions, we made efforts to assure that the schools were geographically dispersed, as well as comprising a mixture of public and private institutions with different levels of academic vigor.

We developed a second, four-page-long survey that was mailed to the directors of all graduate women's studies programs throughout the country. ${ }^{8}$ This survey covered a range of topics-degree requirements, number of course offerings, program emphasis, relations with other disciplines, and the number of faculty and students. In order to be as thorough as possible, we contacted a very broad range of women's studies programs-Ph.D. programs, M.A. programs, certificate programs, and schools that offer a women's studies concentration in another discipline. Surveys were sent to a total of 114 schools, and responses were received from sixty-nine institutions (or 61\%); roughly two-thirds of the responding schools are public and one-third private. The remainder of the paper will be devoted to an analysis of the results of these two surveys, beginning with the responses to the undergraduate survey.

\section{CHARACTERISTICSOF UNDERGRADUATES ENROLLEDINWOMEN'S STUDIES}

We believe the undergraduate respondents represent a cross section of students taking women's studies classes across the 
nation. Slightly over half (55\%) of the sample was comprised of students enrolled in public colleges and universities. As expected, the vast majority (85\%) are women. Nearly $70 \%$ are twenty-one years of age or younger; they were fairly evenly divided between freshmen, sophomores, juniors, and seniors. Racial and ethnic minorities comprised roughly $40 \%$ of the total- 17\% Latino, $7 \%$ Asian American, 6\% African American, 3.5\% Native American/Alaska Native, and $8.5 \%$ indicated a racial/ethnic heritage other than those listed. Nearly $90 \%$ classified themselves as heterosexual. Finally, a broad mix of disciplinary majors were represented with the social sciences and humanities, each providing approximately one-third of the respondents; eight percent declared themselves to be women's studies majors. Undeclared majors and students with science and professional schools majors comprised the rest of the sample. Somewhat surprisingly, only $60 \%$ classified them- selves as feminist. In terms of political ideology, $8 \%$ self-identified as conservative, $39 \%$ as moderate, and $53 \%$ as liberal.

\section{INTEREST IN GRADUATE WOMEN'S STUDIES}

When queried about their post-graduation plans, 57\% indicated they would like to continue their education, pursuing either a professional degree or graduate education. When asked specifically about interest in graduate women's studies, more than three-quarters indicated at least minimal interest; the responses are as follows: strong or very strong interest $(24 \%)$, somewhat interested $(32 \%)$, minimal interest (21\%), and no interest (23\%). Not surprisingly, the women's studies majors expressed significantly greater interest than did the sample as a whole; science and professional school majors expressed the least degree of interest.

The remainder of our analysis will be based on the responses from the 311 students who indicated at least minimal interest in pursuing graduate women's studies education. ${ }^{9}$ The characteristics of the sub-sample differed only minimally 
from that of the larger group (i.e., the percentages of women and feminists increased to $90 \%$ and $70 \%$ respectively). We asked the respondents to indicate their level of interest in eleven different areas of course offerings. Students were allowed to mark multiple areas. As can be seen in Table 1, the respondents expressed extremely high levels of interest in a broad range of topics. Probably the most notable findings are that the students are very interested in courses with an applied focus and have a somewhat lower level of interest in more theoretical courses (e.g., feminist theory/epistemology and queer theory/lesbian politics.)

To further probe the substantive interests of students we asked them a second question about their preferences in

Table 1 Student Interest in Different Substantive Areas of Study

\begin{tabular}{lccc}
\hline Subject Area & \multicolumn{2}{c}{ Percent Expressing Various Levels of Interest } \\
\cline { 2 - 4 } & MinimaVNo Interest & Some Interest & Strong Interest \\
\hline $\begin{array}{l}\text { Gender relations } \\
\text { in United States }\end{array}$ & $10.9 \%$ & $23.9 \%$ & $65.2 \%$ \\
$\begin{array}{c}\text { Cross national } \\
\text { gender relations }\end{array}$ & $13.1 \%$ & $30.1 \%$ & $56.8 \%$ \\
$\begin{array}{l}\text { History of women } \\
\text { Women in arts and }\end{array}$ & $13.5 \%$ & $25.9 \%$ & $60.7 \%$ \\
$\quad$ literature & $19.1 \%$ & $25.6 \%$ & $55.4 \%$ \\
$\begin{array}{l}\text { Women and law } \\
\text { Women and religion }\end{array}$ & $19.4 \%$ & $35.1 \%$ & $45.6 \%$ \\
$\begin{array}{c}\text { Third world } \\
\text { women in the }\end{array}$ & $19.6 \%$ & $21.2 \%$ & $59.1 \%$ \\
$\quad \begin{array}{l}\text { United States } \\
\text { Women and public }\end{array}$ & $20.2 \%$ & $30.9 \%$ & $48.9 \%$ \\
policy & & & \\
Women and politics & $21.3 \%$ & $28.9 \%$ & $50.8 \%$ \\
$\begin{array}{l}\text { Feminist theory and } \\
\text { epistemology }\end{array}$ & $31.1 \%$ & $31.5 \%$ & $47.2 \%$ \\
Queer theory/ & $33.8 \%$ & $32.8 \%$ & $36.1 \%$ \\
lesbian politics & & $32.8 \%$ & $33.5 \%$ \\
\hline
\end{tabular}

Note: The categories are presented in ascending order according to the percentage indicating no or minimal interest in the subject area. 
programmatic focus: "Would you be more or less interested in a women's studies graduate program that has an applied (i.e., real world policy orientation) focus rather than a more theoretical focus?" More than $60 \%$ indicated they would be more interested while less than 5\% indicated that an applied focus would decrease their interest. The remainder responded that it would not affect their interest level.

We then asked students to mark whether they would be interested in courses covering a range of different topics. The course topic with the highest proportion of respondents indicating a very high level of interest was domestic violence, with nearly three-quarters labeling themselves as very interested. Respondents expressed the lowest levels of interest for courses on women, technology, and the environment, women in business, and lesbian politics, each of which had only about a quarter of respondents expressing high levels of interest. The course topics and the levels of interest generated are presented in descending order in Table 2.

The success or failure of graduate women's studies education is not solely determined by the substantive focus and range of course offerings. Other programmatic and institutional characteristics can significantly affect student interest and satisfaction. We included in the survey two questions designed to assess the importance of these factors in deter- mining whether students would be interested in pursuing graduate education in women's studies.

The first question asked respondents to indicate whether seven program characteristics (choice of substantive areas of focus, internships, individually tailored curriculum, interdisciplinary approach, policy clinics, training in technical writing, and training in analytical techniques) would make them more or less interested in a women's studies program. As can be seen from Table 3, more than half of all respondents indicated that these features, with the exception of the technical writing and analytical techniques training, would increase the level of interest. 
Table 2 Student Interest in Different Types of Classes

\begin{tabular}{lccc}
\hline Class Subject & \multicolumn{2}{c}{ Percent Expressing } & Various Levels of Interest \\
\cline { 2 - 4 } & $\begin{array}{c}\text { Minimal/ } \\
\text { No Interest }\end{array}$ & $\begin{array}{c}\text { Some } \\
\text { Interest }\end{array}$ & $\begin{array}{c}\text { Strong } \\
\text { Interest }\end{array}$ \\
\hline Domestic violence & $3.3 \%$ & $24.9 \%$ & $71.8 \%$ \\
Women's legal rights & $3.3 \%$ & $27.8 \%$ & $69.0 \%$ \\
Race and sex & $3.6 \%$ & $28.1 \%$ & $68.3 \%$ \\
$\quad$ discrimination & $4.6 \%$ & $32.9 \%$ & $62.5 \%$ \\
Women and education & $4.6 \%$ & $33.3 \%$ & $55.8 \%$ \\
Employment discrim. & $5.2 \%$ & $31.1 \%$ & $63.6 \%$ \\
Health/reproductive & & & \\
issues & $8.2 \%$ & $33.3 \%$ & $58.5 \%$ \\
Children/family & $14.5 \%$ & $43.4 \%$ & $42.1 \%$ \\
Welfare policies & $14.5 \%$ & $52.0 \%$ & $33.6 \%$ \\
Women's political & & & \\
leadership & $24.1 \%$ & $51.8 \%$ & $24.1 \%$ \\
Women, technology & & $48.8 \%$ & $26.7 \%$ \\
$\quad$ and environment & $24.4 \%$ & $46.2 \%$ & $27.1 \%$ \\
\hline $\begin{array}{l}\text { Lemen in business } \\
\text { Lesbian politics }\end{array}$ & $26.7 \%$ & & \\
\hline
\end{tabular}

Note: The categories are presented in ascending order according to percentage of respondents indicating no or minimal interest in the class subject matter.

Table 3 Student Interest in Program Characteristics

\begin{tabular}{lccc}
\hline Characteristic & \multicolumn{3}{c}{$\begin{array}{c}\text { Percent Expressing More or Less } \\
\text { Interest in Program }\end{array}$} \\
\cline { 2 - 4 } & More Interest & No Change & Less Interest \\
\hline Choice of substantive & $68.2 \%$ & $29.5 \%$ & $2.3 \%$ \\
$\quad$ areas of focus & $67.0 \%$ & $28.4 \%$ & $4.6 \%$ \\
Internships & $59.7 \%$ & $33.3 \%$ & $6.9 \%$ \\
Individually tailored & $58.9 \%$ & $36.2 \%$ & $4.9 \%$ \\
$\quad$ curriculum & & & $8.3 \%$ \\
Interdisciplinary & $53.0 \%$ & $38.7 \%$ & $18.9 \%$ \\
$\quad$ approach & $35.8 \%$ & $45.4 \%$ & $20.9 \%$ \\
Policy clinics & $32.1 \%$ & $47.0 \%$ & \\
Technical writing & Analytical techniques & & \\
\hline
\end{tabular}

Note: The categories are presented in descending order according to percentage of respondents indicating more interest. 
Institutional characteristics also were found to be impor tant. Although some of these characteristics are beyond the control of a particular program, the characteristics that respondents considered to be most desirable can be affected by decisions made at a program level. The quality of faculty was by far the most important characteristic, and that can be influenced by the program. Also the second most important characteristic, close relations with faculty, can be affected by decisions made at the program level. Faculty can be encouraged to develop close working relations with students by making it a factor in salary and promotion decisions. Other factors, most notably, geographic location of the school, cannot be changed at the program level. See Table 4 for a summary of the importance of various institutional characteristics.

Overall, we discovered a high degree of student interest in graduate women's studies education. In terms of the substantive content, the most notable finding is the preference for a program with an applied rather than theoretical focus. This was clear in the responses to questions about both programmatic focus and course topics. In a similar vein, more than half of

Table 4 Importance of Institutional Characteristics

\begin{tabular}{lccc}
\hline Characteristic & \multicolumn{3}{c}{ Percent in Each Category of Importance } \\
\cline { 2 - 4 } & $\begin{array}{c}\text { Not } \\
\text { Important }\end{array}$ & $\begin{array}{c}\text { Somewhat } \\
\text { Important }\end{array}$ & $\begin{array}{c}\text { Very } \\
\text { Important }\end{array}$ \\
\hline $\begin{array}{l}\text { Quality of the faculty } \\
\text { Close relations with }\end{array}$ & $1.3 \%$ & $10.6 \%$ & $88.1 \%$ \\
faculty mentors & $4.0 \%$ & $25.5 \%$ & $70.2 \%$ \\
$\begin{array}{l}\text { Financial aid } \\
\text { Degree/curriculum }\end{array}$ & $11.2 \%$ & $19.1 \%$ & $69.3 \%$ \\
$\begin{array}{l}\text { requirements } \\
\text { Academic reputation } \\
\text { of the school }\end{array}$ & $4.3 \%$ & $28.5 \%$ & $67.2 \%$ \\
Geographic location & $8.3 \%$ & $47.9 \%$ & $43.9 \%$ \\
\hline
\end{tabular}

Note: The categories are presented in descending order according to percentage of respondents indicating characteristic is very important. 
all respondents were very interested in internships and policy clinics. Despite the interest in real world applications, there was only minimal interest in developing skills that were readily transferable to employment outside of academia (i.e, training in technical writing and analytical techniques).

\section{CHARACTERISTICS OF WOMEN'S STUDIES GRADUATE PROGRAMS}

The second survey, which was mailed to the directors of graduate women's studies programs across the nation, uncovered a wide variety in the types of graduate women's studies education being offered. Women's studies minors and certificate programs were the most popular, with just under a third of all schools offering these as options. Far fewer schools provide opportunities for students to earn postgraduate degrees in women's studies. Seventeen percent offer stand-alone women's studies Masters degrees and $10 \%$ offer joint Masters degrees between women's studies and another academic discipline. Not surprisingly, Ph.D. programs were the least common with only $7 \%$ offering a stand-alone women's studies Ph.D. and only 3\% offering a joint Ph.D. in women's studies and another discipline.

To get an overall sense of these programs, we asked a series of questions about the course requirements of each type of pro- gram. Most certificate and concentration programs required between 12 and 25 credit hours, with between 6 and 16 of those hours in women's studies courses. Programs offering the women's studies minor required 1230 total credit hours, with 3 to 25 of those hours in women's studies classes. The women's studies MA degree offerings (both women's studies and joint women's studies with another academic discipline) required 30-50 total hours, with 9 to 35 hours of those hours in women's studies classes. Finally, most of the Ph.D. programs (both women's studies and join women's studies and another 
academic discipline) required 48 to 72 credit hours, with 10 to 18 of those hours in women's studies classes.

To assess the prevalence and integration of women's studies at the graduate level, we asked a series of questions about the numbers and types of courses regularly offered. Although there is a broad range in the number ( 0 to 74$)$ of solely graduate women's studies courses offered each year, two-thirds of the schools offered fewer than six of these classes annually, and half offered three or fewer. Another way that women's studies curriculum can be integrated into graduate education is through the cross-listing of courses. An open-ended question that asked respondents to identify other academic disciplines that cross-list courses with women's studies uncovered a huge disparity across disciplines with the humanities most likely to cross-list and professional schools and the arts the least likely. More than two-thirds of the respondents identified English and history as cross-listing. Other humanities disciplines that were commonly identified included: philosophy $25 \%$, languages $22 \%$, and ethnic studies $17 \%$. Social science disciplines were the second most likely to cross list: sociology $61 \%$, psychology $37 \%$, political science $32 \%$, and anthropology $32 \%$. In contrast, only a small percentage of respondents listed professional schools: education $12 \%$, social work $12 \%$, nursing $9 \%$, law $8 \%$, business $5 \%$, and public policy $3 \%$. Only $5 \%$ and $8 \%$ mentioned drama and art.

Although nearly all (93\%) of the respondents described their programs as inter-disciplinary, some disciplines were far more likely than others to comprise an integral part of the women's studies program. The openness of the humanities and, to a slightly lesser extent, the social sciences that we found in the cross-listing question was confirmed by the responses to a question about the emphasis of the women's studies graduate programs. Nearly three-quarters $(74 \%)$ listed their programs as emphasizing the humanities, and $68 \%$ said they emphasized the social sciences. In contrast, $9 \%$ listed their focus as on the arts and only $3 \%$ said it was the hard sciences. 
We asked another group of questions designed to further identify programmatic emphases. In these questions, respondents were asked to rate the importance of various topics and approaches in their curriculum. These responses were consistent with an emphasis on the humanities and to a lesser extent on the social sciences. More importantly, we found some mismatches between the types of topics ranked as most important by the program directors and those identified as most important in the undergraduate survey. For example, program directors ranked studying feminist theory and epistemology far more highly than did the respondents to the undergraduate survey. A similar mismatch, but in the opposite direction, occurred on the question about the importance of studying women's policy issues. The undergraduate survey respondents were far more interested in studying women's policy issues than were program directors in making it an important part of their curriculum. See Table 5 for a summary of the ranking of topics by the program directors.

Table 5 Program Emphasis on Substantive Areas of Study

\begin{tabular}{lcccc}
\hline Subject Area & \multicolumn{3}{c}{ Different Levels of Importance } \\
\cline { 2 - 5 } & $\begin{array}{c}\text { Low } \\
\text { Importance }\end{array}$ & $\begin{array}{c}\text { Somewhat } \\
\text { Important }\end{array}$ & Important & $\begin{array}{c}\text { Very } \\
\text { Important }\end{array}$ \\
\hline $\begin{array}{c}\text { Race and gender } \\
\text { discrimination }\end{array}$ & $0.0 \%$ & $7.5 \%$ & I0.4\% & $82.1 \%$ \\
$\begin{array}{c}\text { Feminist theory/ } \\
\text { epistemology }\end{array}$ & $4.5 \%$ & $0.0 \%$ & $22.4 \%$ & $73.1 \%$ \\
$\begin{array}{c}\text { Cross national } \\
\text { gender relations }\end{array}$ & $3.0 \%$ & $17.9 \%$ & $19.4 \%$ & $59.7 \%$ \\
$\begin{array}{c}\text { Sexual orientation } \\
\text { issues } \\
\text { omen's policy }\end{array}$ & $4.5 \%$ & $11.9 \%$ & $46.3 \%$ & $37.3 \%$ \\
issues & $21.1 \%$ & $1.5 \%$ & $56.1 \%$ & $21.1 \%$ \\
\hline
\end{tabular}

Note: The categories are presented in descending order according to the percentage indicating that the subject area is very important. 
We also asked a series of questions about program requirements. Roughly two-thirds $(65 \%)$ had a core sequence of required women's studies courses, most often two or three courses. The primary focus in most of these courses is on feminist theory/epistemology, but a few focus on other topics, such as gender studies or cross cultural perspectives on gender. Just over a third (38\%) have a methodology requirement that students must fulfill, but almost none cover applicationsoriented classes, such as data analysis, survey research, statistics, legal research, or technical writing. Just over half (54\%) of those with methods requirements cover qualitative research methods in their classes. Very few of the programs had other applied requirements, such as internships or fieldwork. Only $13 \%$ required internships, and $5 \%$ had fieldwork requirements. However, nearly two-thirds (62\%) required students to complete a major research project on a women's studies topic.

\section{THE VIABILITY OF GRADUATE WOMEN'S STUDIES PROGRAMS}

As we noted earlier, a number of scholars have expressed concerns about the viability of women's studies graduate programs. We asked several questions designed to assess different characteristics that can affect the women's studies' long-term prospects. One of the most important is faculty commitment, which we indirectly assessed through two measures: (1) whether the program had independent faculty lines and (2) the number of faculty regularly teaching in the pro- gram. We found that just under half $(48 \%)$ of the programs had independent faculty lines (i.e., tenure line appointments in women's studies). Among schools with independent faculty lines, most had fewer than five women's studies faculty appointments, although one school actually had eleven. Although the numbers of faculty teaching regularly in women's studies varied enormously (a range from 1 to 60), 
most of the schools had from 2 to 13 faculty who regularly teach courses. Both in terms of having independent faculty lines and faculty willing to regularly teach courses, the graduate women's studies programs are in reasonable shape. It would, of course, be preferable if more women's studies programs had independent faculty appointments.

Some of the other indicators of long term viability are more mixed. Despite the strong interest expressed by undergraduate women's studies students, most existing programs are relatively small. Although one program enrolls 200 graduate students, the average program has fewer than 20 students. The typical program admits between 4 and 7 students per year. Just over half offer some form of financial aid (i.e., fellowships, research assistantships and teaching assistantships). Finally, only half (48\%) of the existing programs classified themselves as financially self-sustaining.

Since degree granting programs are likely to have greater autonomy and be financially self-sustaining than non-degree granting programs (i.e., those with certificates, concentrations and minors), we believe it is useful to consider them separately. In addition, we would expect independent degree programs to have somewhat greater autonomy than dojoint degree programs. Therefore, we will examine each type of degree granting group separately-independent versus joint degree programs at the Masters and Ph.D. levels.

Twelve of the schools in our study offer independent Masters degrees. The numbers of faculty regularly teaching in these programs ranged from 3 to 30 with an average of 9 . All except for three of the schools have women's studies faculty lines, with the number of separate faculty appointments ranging from 3 to 10 . The numbers of students enrolled ranged from 8 to 40 with from 4 to 15 new students enrolled each year. Nearly all $(83 \%)$ of these programs were able to offer financial aid to students. Although most of the financial aid was in the form of research assistantships or teaching assistantships, just under half (42\%) were able to offer fellowships. 
None, however, could offer more than a single fellowship annually. Although one of the programs does not even award a single MA each year, most award between 4 and 9 annually. One awards roughly 15 MA degrees each year. Only one of the directors labeled her program as not being financially selfsustaining.

The situation is somewhat different with respect to the seven programs offering joint Masters degrees. Although these programs typically had more faculty teaching women's studies courses on a regular basis (i.e., from 9 to 60), only three had separate women's studies faculty lines; the numbers of faculty lines were $1,1.5$ and 3.5. The total enrollments ranged from 2 to 35 with between 2 to 13 new students enrolled each year. Two-thirds of these programs offered financial aid to students, mostly in the form of teaching assistantships. Only two could offer students fellowships unconnected to research or teaching. Despite the fact that these programs were less likely to have separate faculty lines and were able to offer less financial aid than the independent MA programs, their financial situation was worse. Most of the directors were unsure how many degrees, if any, are awarded annually, but one director indicated that two are award? each year. Three of the directors described their programs as not financially self-sustaining.

There are only a handful of schools offering Ph.D. degrees in women's studies (five independent and two joint degree programs). Again, we will consider independent and joint degree programs separately, but the small size makes it very risky to generalize. The numbers of faculty teaching in the independent Ph.D. degree programs ranged from 3 to 20. Unlike the independent Masters degree programs, three of the five Ph.D. programs did not have their own faculty lines. Of the two with faculty lines, one had 3.75 faculty and the other had 10. Total enrollments ranged from 5 to 36 with an average of 4 new students admitted annually. Just over half ( 3 schools) were able to offer students financial aid, mostly in 
the form of teaching assistantships. Only two schools have fellowships for women's studies Ph.D. students. Although a couple programs did not yet average a Ph.D. graduate on a yearly basis, the others awarded from 1 to $3 \mathrm{Ph} . \mathrm{D}$. degrees annually. Most of the directors considered their programs to be too new to determine whether they are financially selfsustaining, but two directors indicated their programs were financially viable. None of the directors listed their programs as not financially self-sustaining.

The two joint Ph.D. granting programs are very dissimilar. One has 3 or 4 faculty who regularly teach in the program while the other has 32. The latter has no separate women's studies faculty lines while the former has 6 . The disparities are also evident in the student enrollments- 8 versus 61 , with new enrollments of 1 or 2 per year as opposed to 4 . Both programs offer the entire range of financial aid-fellowships, research assistantships, and teaching assistantships. Despite the differences in the size of the two programs, both offer two fellowships annually. The smaller program does not even average one graduate yearly, while the other averages 10 per year. One program director does not know if her program is financially self-sustaining, but the other director classifies her program as not financially self-sustaining.

\section{CONCLUDING THOUGHTS}

We believe this study provides some important insights into the long-term prospects for graduate women's studies education. Our surveys of undergraduate women's studies students from a range of schools throughout the country uncovered a high degree of student interest in pursuing graduate education in women's studies. However, these surveys also found a significant mis-match between student interests and the emphases of current graduate programs in women's studies. Most notably, these prospective students were very interested 
in applied programs (i.e., those with a real world policy orientation). They also were very interested in programs that included real world applications, such as field work and policy clinics. However, existing programs tend to focus on feminist theory and epistemology and very few have a policy orientation. Only a handful have field work or policy clinic requirements.

In assessing the long-term prospects for graduate women's studies programs, we found both reasons for concern and optimism. Although faculty appear committed to women's studies (as measured by their willingness to regularly teach graduate classes), the colleges and universities appear less committed. We found that fewer than half of the schools had gone the next step-creating separate women's studies faculty lines. Programs that do not make their own faculty appoint-ments are clearly in a more precarious institutional position (i.e., forced to rely on other departments for their teaching faculty). One of the most troubling findings was that only half of the programs classified themselves as financially self-sustaining, a condition that makes them vulnerable during periods of financial retrenchment. However, we did find grounds for optimism in that nearly all of the independent Masters degree programs are financially selfsustaining. (The Ph.D. programs are still too new for us to reach any conclusions about their prospects for success.) We suspect the success of the independent Masters degree programs is directly related to the amount of autonomy they exercise. Not only are these programs accountable for their performance, they are able to tailor their curriculum to meet the needs of their prospective student population in a manner that other types of programs cannot. Given the mis-match that we found between the substantive interests of prospective students in our undergraduate survey and content of existing programs, having the ability to alter program focus and curriculum content may be a key determinant of whether a program is viable in the next century. 


\section{Notes}

1. The authors would like to thank the Irvine Foundation for providing the funds which made this research possible. We also would like to thank the National Women's Studies Association for their assistance in identifying graduate programs in women's studies and all of the individuals who graciously took the time to fill out and administer the surveys that we analyze in this research.

2. See Kidd, Karen and Ande Spencer. 1994. Guide to Graduate Work in Women's Studies, 2nd ed. College Park, MD: National Women's Studies Association.

3. Over the past twenty-five years, scholars have engaged in spirited debates over the relationship between women's studies pedagogy and feminism. On the one side of the dispute are scholars who see feminism as a form of criticism that leads to women's studies, which in turn produces feminist praxis and activism. Scholars on the opposing side also view feminism as a criticism, but one that leads to a new form of knowledge-women's studies. Although individuals associated with the second view disagree about whether women's studies should be considered a separate discipline or a sub-field within traditional disciplines, they agree on its academic orientation. See Rossi and Calderwood 1973; Astin and Parelman 1973; Howe 1977; Howe 1982; Stimpson and Cobb 1986; Chamberlain 1988; Aronson and Swanson 1991; Stake, Roades, Rose, Ellis and West 1994; Guy-Sheftall and Heath 1995; Leatherman 1996; Shteir 1996.

4. See Morris (1998) for a broad discussion of the ongoing prejudice and hostility toward women's studies as an academic discipline.

5. A recent survey of students who received dissertation grants in women's studies revealed that most felt that women's studies at their institutions lacked academic support (Kessler-Harris and Swerdlow 1996).

6. A related concern, but one which will not be taken up in this research, is the question of whether students with women's studies degrees are able to successfully compete in the non-academic job mark.et. Rose (1994) argued that women's studies programs only serve the needs of an elite minority and that few jobs exist for graduates with these degrees. In contrast, Luebke and Reilly (1995), who traced the careers of women with undergraduate women's studies degrees, argued that it can actually give them an advantage in certain job markets. In a similar vein, Wimbush (1995) discovered that women with women's studies Ph.Ds from Emory University were highly employable.

7. As a general rule, survey takers' willingness to respond to questionnaires decreases sharply if the survey instrument exceeds 4 pages (i.e., both sides of two sheets of paper).

8. In order to identify graduate women's studies programs, we started with the list compiled by Kidd and Spencer in 1994. Then in January 1998 we obtained an updated list from the National Women's Studies 
Association. When there were discrepancies in the lists, we contacted the institution to verify the existence of programs and the names and addresses of the directors.

9. To include the respondents with no interest in graduate education in women's studies would have biased the results and significantly decreased their usefulness.

\section{References}

Allen, Judith A. 1997. "Strengthening Women's Studies in Hard Times: Feminism and Challenges of Institutional Adaptation." Women's Studies Quarterly: 358-387.

Aronson, Anne L. and Diana L. Swanson. 1991. "Graduate Women on the Brink: Writng as Outsiders Within." Women's Studies Qy, arterly: 156-173.

Astin, Helen S. and Allison P-arelman. 1973. "Women's Studies in American Colleges and Universities." International Socwl Science Journal 25: 389-400.

Chamberlain, Mariam. 1988. Women in Academe: Progress and Prospects. New York: Russell Sage Foundation.

Guy-Sheftall, Beverly and Susan Heath. 1995. Women's Studies: A Retrospective. New York: Ford Foundation.

Howe, Florence. 1977. Seven I-ears Later: Women's Studies Programs in 1976. Washington DC: National Advisory Council on Women's Educational Programs.

Howe, Florence. 1982. "Feminist Scholarship: The Extent of the Revolution." Change 14: 12-20.

Kessler-Harris, Alice and Amy Swerdlow. 1996. "Pride and Paradox: Despite Success, Women's Studies Faces an Uncertain Future." The Chronicle of Higher Education. 26 April: A64.

Kidd, Karen and Ande Spencer. 1994. Guide to Graduate Work in Women's Studies, 2nd edition. College Park, MD: National Women's Studies Association.

Leatherman, Courtney. 1996. "Making Connections." The Chronicle of Higher Education. 19January: A19.

Luebke, Barbara F. and Mary Ellen Reilly. 1995. Women's Studies Graduates: The First Generation. New York: Teacher's College Press.

Morris, Bonnie J. 1998. "Women's Studies: Prejudice and Vilification Persist." The Chronicle of Higher Education. 19June: A56.

Rose, Hilary. 1994. "Feminist Theory and Women's Activism: Some Problems with Academic Success?" Paper presented to International Sociological Association.

Rossi, Alice and Ann Calderwood. 1973.Academic Women on the Move. New York: Russell Sage Foundation.

Shteir, Ann B. 1996. Graduate Women's Studies: Vz.sions and Realities. North York, Ontario: Inanna Publications and Education, Inc. 
Stake, Jayne E., Laurie Roades, Suzanna Rose, Linda Ellis and Carolyn West. 1994. The Women's Studies Experience: Impetus for Feminist Activism." Psychology of Women Quarterly 18: 17-24.

Stimpson, Catherine R. and Nina Kressner Cobb. 1986. Women's Studies in the United States: A Report to the Ford Foundation. New York: Ford Foundation.

Wimbush, Donald. 1995. "Women's Studies Programs Give Graduates Career Edge: Emory University Celebrates First Ph.D. Recipients." Black Issues in Higher Education. 13July: 48-51. 